\title{
PRODUCTION AND PURIFICATION OF PROTEASE BY FUNGUS ISOLATED FROM THE BRAZILIAN DRY TROPICAL FOREST (CAATINGA)
}

\author{
T. P. NASCIMENTO' ${ }^{1}$, R. M. P. B. COSTA ${ }^{2}$, A. CONVERTI', e A. L. F. PORTO ${ }^{2}$ \\ ${ }^{1}$ Laboratório de Imunopatologia Keizo Asami (LIKA), Universidade Federal de Pernambuco \\ ${ }^{2}$ Laboratório de Tecnologia de Bioativos (LABTECBIO), Universidade Federal Rural de \\ Pernambuco \\ ${ }^{3}$ Universidade de Genova, Polo de Engenharia Química \\ E-mail para contato: thiago_pajeu@hotmail.com
}

\begin{abstract}
RESUMO - A demanda industrial por enzimas proteolíticas tem estimulando a busca por novas fontes de enzimas. As enzimas fúngicas são preferidas sobre as enzimas bacterianas, por serem mais eficazes e fáceis de extrair. O objetivo deste trabalho foi à purificação de proteases produzidas na fermentação em estado sólido por Mucor subtilissimus UCP 1262. O extrato bruto foi analisado utilizando 3 atividades proteoliticas diferentes, atividade colagenolítica (161,4 $\mathrm{U} / \mathrm{ml})$, queratinolítica $(39,6 \mathrm{U} / \mathrm{ml})$ e fibrinolítica $(26,1 \mathrm{U} / \mathrm{ml})$. Após precipitação com sulfato de amônio, as frações ativas com atividade fibrinolitica foram dialisadas em tampão Tris- $\mathrm{HCl} 15 \mathrm{mM}, \mathrm{pH}$ 8, carregadas na coluna de troca iônica DEAE-Sephadex A50 e gel filtração (Superdex 75 HR10/300). A enzima purificada mostrou atividade frente a um substrato cromogênico de quimotripsina, a SDS-PAGE mostrou uma protease fibrinolítica com massa molecular de aproximadamente $70 \mathrm{kDa}$, e uma atividade específica de 25,93 U/mg. Essas características sugerem que a enzima pode ser produzida de forma rentável e eficiente para uso na terapia trombolitica.
\end{abstract}

Palavras chave: protease, Mucor, atividade fibrinolítica, quimotripsina, Caatinga, fermentação em estado sólido.

\begin{abstract}
The industrial demand for proteolytic enzymes is stimulating the search for new enzyme sources. Fungal enzymes are preferred over bacterial enzymes, and more effective and easy to extract. The aim of this work was the purification of proteases produced in solid state fermentation by Mucor subtilissimus UCP 1262. The crude extract was analyzed using 3 different proteolytic activities, namely collagenolytic (161.4 U/ml), keratinolytic $(39.6$ $\mathrm{U} / \mathrm{ml})$ and fibrinolytic $(26.1 \mathrm{U} / \mathrm{ml})$. After ammonium sulfate precipitation, the active fractions with fibrinolytic activity were dialyzed in $15 \mathrm{mM}$ Tris-HCl buffer, pH 8, loaded onto DEAE-Sephadex A50 ion-exchange column and gel filtered through Superdex 75 HR10/300. The purified enzyme showed activity against a chromogenic chymotrypsin substrate, SDS-PAGE showing a molecular mass of
\end{abstract}


suggest that the enzyme could be profitably and efficiently produced in large amounts for thrombolytic therapy.

Key words: protease, Mucor, fibrinolytic activity, chymotrypsin, Caatinga, solid state fermentation.

\section{INTRODUCTION}

Proteases are one of the most important groups of enzymes. Being a class of enzymes belonging to peptidyl-peptide hydrolases, occupying a pivotal position with respect to their application wide applicability in the medical field and industrial, representing approximately $60 \%$ of the enzymes sold worldwide (BARRET et al., 2001; SINGH et al., 2003). Because of their high efficiency, versatility in biotechnological applications, specificity and stability toward $\mathrm{pH}$, salt, temperature, organic solvents, metal ions and surfactants, alkaline proteases are in high demand (RAVAL et al., 2014).

Peptidases are enzymes that have been produced by microorganisms in different types of culture media based on agro-industrial waste, such as wheat bran and soybean flour (MEENA et al., 2013). The use of proteases for therapeutic applications has been one of the goals of the industry pharmaceutical in recent years, since the catalytic activity of these enzymes permits the use of lower doses for treatments, with a target potential and greater efficiency, and reduce side effects of existing drugs, while maintaining the desired therapeutic benefits and reducing costs becoming interesting for industrial pharmaceutical industry, it is estimated that about 5 to $10 \%$ all pharmaceutical targets for drug development are proteases (DRAG AND SALVESEN, 2010). Microorganisms are excellent sources of proteases because they have wide biochemical diversity, can be easily cultivated and maintained at low cost, and can be genetically manipulated to improve or modify the final product (ADRIO and DEMAIN, 2014). These can be isolated from soils of some biomes, among them the Caatinga an exclusive biome of the Brazilian northeast bounded to the east and west by the Atlantic and Amazonian forests, respectively, and to the south by the Cerrado having an area of 735,000 $\mathrm{km}^{2}$ (LEAL et al., 2005).

Solid state fermentation (SSF), which is defined as the fermentation on solid substrate, is carried out in the absence or near absence of free water, even though the substrate must possess enough moisture to support microbial growth and metabolism. The solid matrix could be either the source of nutrients or simply a support impregnated with proper nutrients that allow the development of microorganisms (MASUTTI et al., 2012). SSF is particularly advantageous for industrial enzyme production by filamentous fungi because it enables the use of agro-industrial residues as solid substrate, acting as carbon and energy source (PIROTA et al., 2014). The aim of this work was the purification of proteases produced in SSF by Mucor subtilissimus UCP 1262 isolated from soil of the Brazilian Caatinga biome.

\section{MATERIAL AND METHODS}

\subsection{Production of proteolytic enzymes by SSF and Enzyme extraction}

Mucor subtilissimus UCP 1262 was isolated from the Caatinga soil, Serra Talhada, PE- 
Brazil and deposited in the culture collection of the Catholic University of Pernambuco, Recife-PE, Brazil. The fungus was inoculated to a final concentration of $10^{7}$ spores $/ \mathrm{mL}$ in 125 $\mathrm{mL}$ Erlenmeyer flasks,

containing $5 \mathrm{~g}$ of wheat bran with a granulometry from 0.6 to $2.0 \mathrm{~mm}$ (moisture of $50 \%$ ), and incubated at $25^{\circ} \mathrm{C}$ for 72 hours. The enzyme was extracted after 72 hours of fermentation. After addition of $7.5 \mathrm{~mL}$ of $245 \mathrm{mM}$ sodium phosphate buffer, $\mathrm{pH} 7$, per $\mathrm{g}$ of substrate, flasks were placed in an orbital shaker at $150 \mathrm{rpm}$ for $90 \mathrm{~min}$ at room temperature. After this period, the suspension was centrifuged at 3,500 $\mathrm{xg}$ for $10 \mathrm{~min}$ at $4^{\circ} \mathrm{C}$, and the supernatant used for determination of different enzyme activities.

\subsection{Enzyme activities}

Protease activity - The assay was determined according to Ginther et al., 1979. One unit of protease activity was defined as the amount of enzyme that produces an increase in the absorbance of 0.1 per hour at $420 \mathrm{~nm}$. Experiments were performed in triplicate. Collagenase activity - The assay for azo dye-impregnated collagen (Azocoll) was carried out according to method developed by Chavira et al. (1984). One unit of collagenase activity was defined as the amount of enzyme per $\mathrm{mL}$ of crude extract that leads, after $1 \mathrm{~h}$ of incubation, to an increase in the absorbance of 0.01 at $520 \mathrm{~nm}$, as a result of the formation of azo dye-linked soluble peptides. Keratinase activity - Keratinase activity was determined according to Cheng-Gang et al. (2008). One unit of keratinase activity was defined as the amount of enzyme responsible for an increase in the absorbance of 0.01 at $595 \mathrm{~nm}$ after the reaction with keratin azure for 1 $\mathrm{h}$ at $\mathrm{pH} 8.0$ and $50^{\circ} \mathrm{C}$. Fibrinolytic activity - Fibrinolytic activity was determined by the spectrophotometric method described by Wang et al. (2011). In this assay, 1 fibrin degradation unit (U) of enzyme activity was defined as the amount of enzyme able to cause a 0.01 increase per minute in the absorbance. Each experiment was performed in triplicate, and the results, after correction against blank samples, were expressed as mean values. Amidolytic activity Amidolytic activity was measured qualitatively by the method described by Kim et al. (1996) using as synthetic substrates: N-Succinyl-Ala-Ala-Pro-Phe p-nitroanilide - Chymotrypsin substrate (S7388 Sigma) and Gly-Arg-p-nitroanilidedihydrochloride - Urokinase and plasmin substrate (G8148 Sigma). The Protein content was determined by the method described by Bradford (1976).

\subsection{Purification of protease with fibrinolytic activity}

After precipitation of the crude extract with ammonium sulfate up to $100 \%$ of saturation, the active fractions with fibrinolytic activity were loaded into a DEAE-Sephadex A50 ionexchange column $(25 \times 12 \times 2.0 \mathrm{~cm})$ equilibrated with $150 \mathrm{mM}$ Tris-HCl buffer, $\mathrm{pH} 8$. The sample was then eluted with the same buffer containing $0.5 \mathrm{M}$ potassium chloride. The protein-containing fraction was pooled, and the enzyme solution concentrated for further analysis. All the process was monitored at $280 \mathrm{~nm}$ absorbance. The main fractions with fibrinolytic activity were dialyzed in $15 \mathrm{mM}$ Tris- $\mathrm{HCl}$ buffer, $\mathrm{pH}$. The dialysate was concentrated by lyophilization and subsequently gel filtrated through Superdex 75 HR10/300 AKTA that had previously been equilibrated with $100 \mathrm{mM}$ Tris- $\mathrm{HCl}$ buffer, $\mathrm{pH}$ 8.0, at a flow rate of $0.5 \mathrm{~mL} / \mathrm{min}$. The fractions possessing protease activity were pooled and concentrated.

\subsection{SDS-PAGE and Fibrin zymography}

Sodium dodecyl sulphate-polyacrylamide gel electrophoresis (SDS-PAGE) was carried out using a $12 \%$ polyacrylamide running gel according to the method of Laemmli (1970). The Fibrin zymography was assessed using a fibrin gel according to Kim et al. (1998). 


\section{RESULTS AND DISCUSSIONS}

In previous study by Nascimento et al. (2015) we found that a wheat bran amount of $3 \mathrm{~g}$, a moisture content of $50 \%$, a temperature of $30^{\circ} \mathrm{C}$ and a fermentation time of 72 hours were the best conditions for protease production by M. subtilissimus UCP 1262; therefore, they were used in these experiments for enzyme production.

The crude extract showed collagenase, fibrinolytic, protease and keratinase activities of $161.4 ; 26.1 ; 102.9$ and $39.6 \mathrm{U} / \mathrm{mL}$, respectively. A similar study conducted by Sharkova et al. (2015) with fungal species with fibrinolytic and collagenase activities revealed that, although eighteen micromycetes exhibited proteolytic activity, species belonging to the Mucor genus showed specific collagenase activity but no appreciable proteolytic activity towards fibrin. Another study by Shirasaka et al (2012) about protease production by Aspergillus oryzae KSK-3 isolated from commercial rice-koji for miso brewing, showed a fibrinolytic activity of $21.8 \mathrm{U} / \mathrm{mL}$,less activity than that found in our work. Kim (2003) observed that fourteen species of fungi associated with feather belonging to ten genera, including Mucor, showed keratinase activity in submerged fermentation, but the species that provided the best results were belonging to the genus Aspergillus with activity in the range 10-15 U/mL, well below that of the crude extract produced in this work by Mucor subtilissimus $(39.6 \mathrm{U} / \mathrm{mL})$. The amidolytic activity of the purified enzyme was then assessed towards two chromogenic substrates. Since the highest degree of specificity was observed for N-Succinyl-Ala-Ala-ProPhe p-nitroanilide, the fibrinolytic protease purified from Mucor subtilissimus UCP 1262 was considered to be a chymotrypsin-like one. Similar fibrinolytic activity was reported from Fomitella fraxinea (LEE et al. 2006) and Perenniporia fraxinea mycelia (KIM et al. 2008).

Among the proteolytic activities detected in this work, the fibrinolytic one was chosen to be purified because no enzyme of this kind has so far been reported in the literature for fungal species of the Mucor genus, as well as because of its pharmacological and therapeutic concern. The ever-increasing interest in proteins used for a vast range of pharmaceutical applications becomes obvious considering the number of reports related to the production and purification of these types of macromolecules (ASENJO and ANDREWS, 2012). So, the fibrinolytic enzyme was purified by a combination of 3 chromatographic steps as summarized in Table 1. The enzyme fraction obtained using 40-60\% saturation with ammonium sulfate showed an increase in the fibrinolytic activity $(10.08 \mathrm{U} / \mathrm{mg})$ compared with the crude extract, being the fraction used for subsequent steps., while that reported by Shirasaka et al. (2012) for a fibrinolytic protease from Aspergillus oryzae KSK-3 using 0-60\% saturation is similar to that obtained in the present work.

After anion exchange chromatography with DEAE Sephadex, the specific fibrinolytic activity was $19.96 \mathrm{U} / \mathrm{mg}$. The main fractions with fibrinolytic activity collected after ion exchange chromatography were subjected to gel-filtration chromatography with Superdex 75 (HR10/300), resulting in three major fractions, only the first of which showed fibrinolytic activity (specific activity of $25.93 \mathrm{U} / \mathrm{mg}$ ), with a percent recovery of $4.84 \%$. Shirasaka et al. (2012), using the same gel-filtration system to purify a fibrinolytic enzyme from Aspergillus oryzae KSK-3, obtained $0.005 \%$ of enzyme recovery. 
Table 1. Purification protocol adopted for purification of fibrinolytic protease from Mucor subtilissimus UCP 1262 and related results.

\begin{tabular}{|c|c|c|c|c|c|}
\hline $\begin{array}{c}\text { Purification } \\
\text { step }\end{array}$ & $\begin{array}{c}\text { Total } \\
\text { Protein }(\mathrm{mg})\end{array}$ & $\begin{array}{c}\text { Total } \\
\text { Activity }(\mathrm{U} / \mathrm{mL})\end{array}$ & $\begin{array}{c}\text { Specific acti } \\
(\mathrm{U} / \mathrm{mg})\end{array}$ & $\begin{array}{c}\text { Purification } \\
\text { fold }\end{array}$ & $\begin{array}{c}\text { Recovery } \\
(\%)\end{array}$ \\
\hline Crude extract & 107.20 & 498.25 & 4.64 & 1.00 & 100.00 \\
\hline $\begin{array}{l}\text { Ammonium } \\
\text { sulfate } \\
\text { precipitation }\end{array}$ & 42.73 & 430.75 & 10.08 & 2.17 & 86.45 \\
\hline $\begin{array}{l}\text { DEAE } \\
\text { Sephadex } \\
\text { (Anion } \\
\text { exchange) }\end{array}$ & 5.41 & 108.00 & 19.96 & 4.30 & 21.67 \\
\hline $\begin{array}{l}\text { Superdex } 75 \\
\text { HR } 10 / 300 \\
\text { (Gel filtration) }\end{array}$ & 0.93 & 24.12 & 25.93 & 5.58 & 4.84 \\
\hline
\end{tabular}

The SDS-PAGE analysis of the only fraction exhibiting fibrinolytic activity shows (Figure 1) a single homogenous band corresponding to a molecular weight of approximately $70 \mathrm{kDa}$. The fibrinolytic activity was confirmed by fibrin zymography (Figure 1C) showing a clear sharp band with molecular weight close to that revealed by SDS-PAGE and estimated by AKTA gel filtration. Such a molecular weight of the purified enzyme $(70 \mathrm{kDa})$ is larger than the majority of known fibrinolytic enzymes described in the literature for Fusarium sp. BLB (27 kDa) (UEDA et al., 2007); Fusarium sp. CPCC (28 kDa) (Wu et al., 2009) and Armillaria mellea $(21 \mathrm{kDa})$ (WU et al., 2009), but close to the one reported for Bionectria sp. (80 kDa) (ROVATI et al., 2010).

Figure 1. Molecular weight determination of fibrinolytic protease purified from Mucor subtilissimus UCP 1262 using by SDS-PAGE (A); (B) and fibrin zymography (C). (M) protein standard marker (Full Range RPN800E - GE Healthcare); (A) SDS-PAGE was carried out on a $12 \%$ polyacrylamide gel and was stained with silver nitrate showed the purified fibrinolytic protease by DEAE Sephadex; (B) Purified fibrinolytic protease by Superdex 75 HR10/300; (C) Fibrin zymography was carried out on a $12 \%$ polyacrylamide gel contain fibrin and was stained with Coomassie Brilliant Blue R-250.

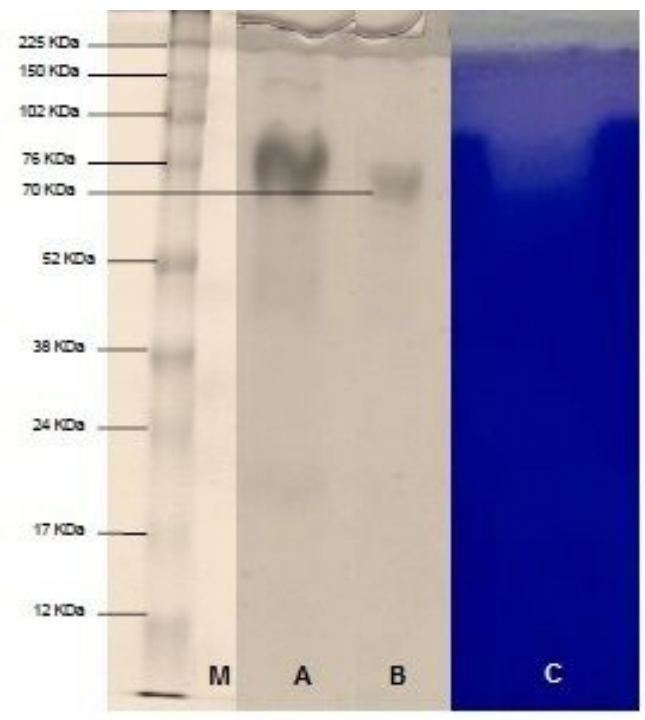




\section{CONCLUSIONS}

A fibrinolytic enzyme purified from Mucor subtilissimus UCP 1262 exhibited a substrate specificity close to chymotrypsin proteases, This protease shows a high degree of specificity toward fibrin, and could be useful in thrombolytic therapy acting as a direct agent in fibrin clot. Therefore, the fungi Mucor may become a source for thrombolytic agents to treat thrombosis. Further studies on the characterization of this enzyme and your application in vitro and in vivo are proceeding.

\section{REFERENCES}

ADRIO, J.; DEMAIN, A. Microbial enzymes: tools for biotechnological processes. Biomol. 4, 117-139, 2014.

ASENJO, J. A.; ANDREWS, B. A. Aqueous two-phase systems for protein separation: phase separation and applications. J Chromatogr A. 1-10, 2012.

BARRET, A. J.; RAWLINGS, N. D.; O'BRIEN, E.A. The MEROPS data base as a protease information system. J Struct Biol. 134, 95-102, 2001.

BRADFORD, M. M. A rapid and sensitive method for the quantitation of microgram quantities of protein utilizing the principle of protein-dye binding. Anal Biochem. 72, 248254, 1976.

CHAVIRA, R. J.; BURNETT, T. J.; HAGEMAN, J. H. Assaying proteinases with azocoll. Anal Biochem.136, 446-50, 1984.

CHENG-GANG, C.; JI-SHUANG, C.; JIONG-JIONG,Q.; YUN, Y.; XIAO-DONG, Z. Purification and characterization of keratinase from a new Bacillus subtilis strain. $\mathbf{J}$ Zhejiang University Scie B. 9,713-720, 2008.

DRAG, M.; SALVESEN, G. S. Emerging principles in protease-based drug discovery. Nature reviews. Drug discovery. 9, 690-701, 2010.

GINTHER, C. L. Sporulation and the production of serine protease and cephamycin C by Streptomyces lactamdurans. Antimicrob Agents Ch.15, 522-526, 1979.

KIM, J. D. Keratinolytic activity of five Aspergillus species isolated from poultry farming soil in Korea. Mycobiol. 31, 157-161, 2003.

KIM, J. S.; KIM, J. E.; CHOI, B. S.; PARK, S. E.; SAPKOTA, K.; KIM, S.; LEE, H. H.; KIM, C. S.; PARK, Y.; KIM, M. K.; KIM, Y. S.; KIM, S. J. Purification and characterization of fibrinolytic metalloprotease from Perenniporia fraxinea mycelia. Mycol Res. 112, 990998, 2008.

KIM, S. H., CHOI, N. S., LEE, W. Y. Fibrin zymography: a direct analysis of fibrinolytic enzymes on gels. Anal Biochem. 263, 115-116, 1998.

KIM, W.; CHOI, K.; KIM, Y.; Park, H.; CHOI, J.; LEE, Y.; OH, H.; KWON, I.; LEE, S. Purification and characterization of a fibrinolytic enzyme produced from Bacillus sp. strain CK 11-4 screened from Chungkook-Jang. Appl Environ Microb. 62, 2482-2488, 1996. 
LAEMMLI, U. K. Cleavage of structural proteins during the assembly of the head of bacteriophage T4. Nature. 227, 680-685, 1970.

LEE, J. S.; BAIK, H. S.; PARK, S. S. Purification and characterization of two novel fibrinolytic proteases from mushroom, Fomitella fraxinea. J Microbiol Biotechn. 16, 264 $271,2006$.

MASUTTI, D. C.; BORGOGNONE, A.; SETTI, L. Production of enzymes from rice husks and wheat straw in solid state fermentation. Chem Eng Transact. 27, 133-138, 2012.

MEENA, P.; TRIPATHI, A. D.; SRIVASTAVA, S.; JHA, A. Utilization of agro-industrial waste (wheat bran) for alkaline protease production by Pseudomonas aeruginosa in SSF using Taguchi (DOE) methodology. Biocatal Agr Biotechnol. 2, 210-216, 2013.

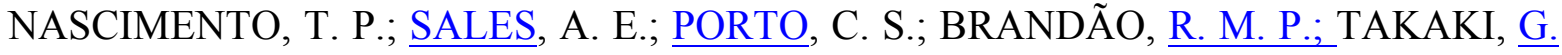
M. C.; TEIXEIRA, J. A. C.; PORTO, T. S.; PORTO, A. L. F. Production and characterization of new fibrinolytic protease from Mucor subtilissimus UCP 1262 in solid-state fermentation. Adv Enzyme Res. 3, 81-91, 2015.

PIROTA, R. D. P. B.; DELABONA, P. S.; FARINAS, C. S. Enzymatic hydrolysis of sugarcane bagasse using enzyme extract and whole solid-state fermentation medium of two newly isolated strains of Aspergillus oryzae, Chem Eng Transact. 38, 259-264, 2014.

RAVAL, V. H.; PILLAI, S.; RAWAL, C. M.; SINGH, S. P. Biochemical and structural characterization of a detergent-stable serine alkaline protease from seawater haloalkaliphilic bacteria. Process Biochem. 49, 955-962, 2014.

ROVATI, J. I.; DELGADO, O. D.; FIGUEROA, L. I. C.; FARINA, J. I. Novel source of fibrinolytic activity: Bionectria sp., an unconventional enzyme-producing fungus isolated from Las Yungas rainforest (Tucuman, Argentina). World J Microb Biot. 26, 55-62, 2010.

SHARKOVA, T. S.; KURAKOVA, A. V.; OSMOLOVSKIY, A. A.; MATVEEVA, E. O.; KREYER, V. G.; BARANOVA, N. A.; EGOROV, N. S. Screening of producers of proteinases with fibrinolytic and collagenolytic activities among micromycetes. Microbiol. 84, 359-364, 2015.

SHIRASAKA, N.; NAITOU, M.; OKAMURA, K.; KUSUDA, M.; FUKUTA, Y.; TERASHITA, T. Purification and characterization of a fibrinolytic protease from Aspergillus oryzae KSK-3. Mycoscience, 53, 354-364, 2012.

SINGH, J.; VOHRA, R. M.; SAHOO, D. K. Enhanced production of alkaline protease by Bacillus sphaericus using fed-batch culture. Process Biochem. 39, 1093-1101, 2003.

UEDA, M.; KUBO, T.; MIYATAKE, K.; NAKAMURA, T. Purification and characterization of fibrinolytic alkaline protease from Fusarium sp. BLB. Appl Microbiol Biot. 74, 331-338. 2007

WANG, S. L., WU, Y. Y., LIANG, T. W. Purification and biochemical characterization of a nattokinase by conversion of shrimp shell with Bacillus subtilis TKU007. New Biotechnol. 28, 196-202, 2011.

WU, B.; WU, L.; CHEN, D.; YANG, Z.; LUO, M. Purification and characterization of a novel 


\section{ACKNOWLEDGMENTS}

The authors acknowledge the financial support of CAPES (Coordenação de Aperfeiçoamento de Pessoal de Nível Superior, Brasilia, Brasil), FACEPE (Fundação de Amparo à Ciência e Tecnologia do Estado de Pernambuco, Recife, Brasil) and CNPq (Conselho Nacional de Desenvolvimento Científico e Tecnológico, Brasilia, Brasil). The authors wish to thank approval of this project in the network RENNORFUN Notice MCT/CNPq/MMA/MEC/CAPES/FNDCT, Ação Transversal/FAPs n.47/2010, Sistema Nacional de Pesquisa em Biodiversidade-SISBIOTA/Bras 


\title{
NANOBIOELETRODO ELETROQUÍMICO BASEADO EM NANOPARTÍCULAS DE ÓXIDO DE ZINCO E CONCANAVALINA A PARA DETECÇÃO DO VÍRUS ZIKA.
}

\author{
D. B. de S. SILVA ${ }^{1}$, E.P. SIMÃO ${ }^{1,2}$, M. T. CORDEIRO ${ }^{3}$, L. H. V. G. GIL ${ }^{3}$, C. A. S \\ ANDRADE $^{1,4}$, M.D.L. OLIVIERA ${ }^{1,4}$ \\ ${ }^{1}$ Laboratório de Biodispositivos Nanoestruturados (BioNano), Universidade Federal de \\ Pernambuco (UFPE). \\ 2 Programa de Pós-graduação em Ciências Biológicas, Universidade Federal de \\ Pernambuco (UFPE). \\ ${ }^{3}$ Departamento de Virologia e Terapia Experimental, Centro de Pesquisas Aggeu \\ ${ }^{4}$ Departamento de Bioquímica, Universidade Federal de Pernambuco(UFPE).
} Magalhães.

E-mail para contato: dammy9_barbosa@outlook.com

\begin{abstract}
RESUMO - As arboviroses são um grande problema de saúde pública mundial devido as graves consequências e sequelas que podem provocar a saúde humana, que variam de complicações neurológicas ao óbito. O vírus zika ganhou destaque mundial nos últimos anos por conta das graves consequência neurológicas nos recém nascidos de mães infectadas durante a gestação. Assim como o zika, outros arbovírus como dengue, chikungunya e febre amarela reurbanizaram e estão provocando diversos problemas a saúde da população. O presente trabalho propõe um novo método diagnóstico para identificação e distinção de infecções pelo vírus zika e febre amarela, utilizando nanobioleletrodo eletroquímico baseado em nanoparticulas de oxido de zinco e concanavalina A. Neste estudo foram utilizados o vírus zika e a febre amarela para avaliar a capacidade de interação desses vírus com a lectina concanavalina $A$, imobilizada a uma plataforma nanoestruturada, por meio das técnicas de voltametria cíclica e impedância eletroquímica. O vírus zika apresentou uma maior interação com lectina em estudo, sendo uma ferramenta útil para o diagnóstico clínico.
\end{abstract}

PALAVRAS-CHAVE: Biossensor; Zika; Febre Amarela; Concanavalina A.

\begin{abstract}
Arboviruses are a major global public health problem because of the serious consequences and sequelae that can cause human health, ranging from neurological complications to death. The zika virus has gained worldwide prominence in recent years due to the serious neurological consequence in newborns of infected mothers during pregnancy. Like zika, other arboviruses such as dengue, chikungunya and yellow fever have re-urbanized and are causing various health problems for the population. The present work proposes a new diagnostic method for the identification and distinction of infections by zika virus
\end{abstract}

